\title{
A Novel Organometallic Rhenium Salt: DNA-Binding and Cytotoxicity Studies on Pancreatic, Breast and Lymphoma Cancers
}

\section{Christopher C. Krauss}

Morgan State University

Birsen Y. Varisli

Morgan State University

Angela J. Winstead

Morgan State University

Paul T. Wilder

University of Maryland School of Medicine

David J. Weber

University of Maryland School of Medicine

\section{Fazlul H. Sarkar}

Wayne State University School of Medicine

Yongchao Zhang

Morgan State University

Fasil A. Abebe

Morgan State University

Sujan Ghimire

Morgan State University

Pumtiwitt C. McCarthy

Morgan State University

Saroj K Pramanik

Morgan State University

Douglas M. Ho

Princeton University

Kayla Johnston

Elizabeth City State University

Hirendra N Banerjee

Elizabeth City State University

Santosh K Mandal ( $\square$ santosh.mandal@gmail.com )

Morgan State University https://orcid.org/0000-0002-7348-8217 


\section{Research Article}

Keywords: Organorhenium salt, pancreatic cancer, breast cancers, lymphoma, DNA, titrations

Posted Date: March 22nd, 2021

DOl: https://doi.org/10.21203/rs.3.rs-165666/v1

License: (c) (i) This work is licensed under a Creative Commons Attribution 4.0 International License. Read Full License 


\section{Abstract}

DNA-binding studies of a variety of rhenium(I) tricarbonyl complexes are known. Primarily the rhenium complexes bind to DNA through intercalation or minor groove or both. We synthesized a novel organometallic salt of the type, $[\operatorname{Re}(\mu-\mathrm{H}) \operatorname{Re}]^{+}\left[\operatorname{Re}(\mu-\mathrm{OR})_{3} \operatorname{Re}\right]^{-}$. The UV-vis and emission spectroscopic titrations and viscosity studies indicate that the salt binds to DNA through partial intercalation. A variety of mono-, di-, and trinuclear rhenium(I) carbonyl complexes are known to exhibit cytotoxicity against numerous cancer cell lines. Examples of the cytotoxicity of tetranuclear rhenium (I) tricarbonyl complexes are rare. We have found that the tetranuclear, novel organometallic salt is highly potent on numerous cancer cells. The $\mathrm{IC}_{50}$ values (concentrations required to induce $50 \%$ cell deaths) are $0.220 \mu \mathrm{M}$ on BxPC-3 pancreatic cancer cells, $0.298 \mu \mathrm{M}$ on estrogen receptor positive MCF-7 breast cancer cells, $0.948 \mu \mathrm{M}$ on triple negative MDA-MB-231 breast cancer cells, and $0.300 \mu \mathrm{M}$ on U-937 lymphoma cells.

\section{Introduction}

Reactions of group VII metal carbonyls with monophosphines, diphosphines and diimines in alcohols provide a wide variety of organometallic complexes [1-10]. The reaction of $\operatorname{Re}_{2}(\mathrm{CO})_{10}$ with phen $(1,10-$ phenanthroline) in refluxed 1-pentanol produced the expected alkoxide, fac-(CO) $)_{3}$ (phen) $\mathrm{ReOC}_{5} \mathrm{H}_{11}$ and a dirhenium complex (minor product) [11]. Surprisingly, the reaction of $\operatorname{Re}_{2}(\mathrm{CO})_{10}$ with 2, 9-dimethyl-1,10phenanthroline (aka, neocuproin) in refluxed 1-pentanol afforded the corresponding alkoxide, fac$(\mathrm{CO})_{3}$ (neocuproin) $\mathrm{ReOC}_{5} \mathrm{H}_{11}$ (major product, 1 ) and an organorhenium salt (minor product, 2 ) (Scheme 1). 2 has a hydrido-bridged dirhenium hexacarbonyl cation and a trispentyloxo-bridged dirhenium hexacarbonyl anion [12] as shown in Scheme 1: see Scheme 1 in the supplementary files.

The tetranuclear rhenium (I) complex $[\operatorname{Re}(\mu-\mathrm{H}) \operatorname{Re}]^{+}\left[\operatorname{Re}(\mu-\mathrm{OR})_{3} \operatorname{Re}\right]^{-}, 2$ is structurally unique and different from the known tetranuclear rhenium (I) molecular rectangles [9,10], cyclic tetranuclear platinum (II) and palladium (II) [13], ruthenium (II) [14], copper(II) [15], silver (I) [16], tin(IV) [17] and a whole host of related other tetranuclear metal complexes. Anticancer properties of numerous mono and dinuclear and a few trinuclear rhenium (I) complexes are known [18-29]. However, examples of biological properties of tetranuclear rhenium complexes are scarce $[9,12]$. Herein, we report a preliminary in vitro binding studies of the tetranuclear rhenium (I) complex 2 with calf thymus DNA (CT-DNA) using various biophysical techniques and the anticancer activity of 2 on BxPC-3 pancreatic cancer, estrogen receptor positive MCF-7 breast cancer, triple negative MDA-MB-231 breast cancer, and U-937 lymphoma cells.

\section{Materials And Methods}

\section{Materials and reagent}

Commercially available analytical grade solvents were used without further purification. Dirhenium decacarbonyl was obtained from Pressure Chemical Company, Pittsburgh, Pennsylvania. Neocuproine was purchased from commercial sources. Calf thymus DNA (CT-DNA) and ethidium bromide (EB or EtBr) 
were both purchased from Sigma Aldrich. Cell lines (MCF-7, MDA-MB-231, BxPC-3 and U-937) were purchased directly from ATCC. DMEM and MEM were both obtained from Cellgro. RPMI-1640, fetal bovine serum (FBS), penicillin (Penn), streptomycin (Strep), trypsin, and Alamar Blue reagent were all purchased from Thermo Fisher Scientific. MTT (3-(4,5-dimethyl-2-thiazolyl)-2,5-diphenyl-2H-tetrazolium bromide) and other materials for the cell cultures were obtained from Gibco and other commercial sources.

\section{Synthesis of 2}

The synthesis of compound 2 has been previously published [12]. In brief, a mixture of $\operatorname{Re}_{2}(\mathrm{CO})_{10}$ and neocuproine in a 1:2 mole ratio was refluxed for $24 \mathrm{~h}$ and cooled to room temperature for another $24 \mathrm{~h}$. This mixture was filtered and the reddish brown crystalline minor product 2 was separated by filtration. Complex 2 was characterized spectroscopically and through X-ray crystal structure determination [12]

\section{DNA-binding studies}

\section{Electronic absorption spectroscopy}

A measured amount of the tetranuclear rhenium complex 2 was dissolved in DMSO. Tris buffer at $\mathrm{pH} 7.2$ $(3000 \mu \mathrm{L})$ was placed in the reference cuvette. The sample cuvette contained the same volume of buffer. Both cuvettes were diluted with equal amounts of neat DMSO (reference) and the DMSO solution of the complex (sample). To perform the titrations, a measured amount of a DNA stock solution in Tris buffer, $\mathrm{pH} 7.2$ was added to each cuvette to achieve a desired DNA concentration in each cuvette. Solutions were mixed thoroughly by repeated inversion of the cuvettes. After an incubation time of $15 \mathrm{~min}$, the absorption spectra (225-700 nm) were recorded. Absorption titrations were carried out by gradually increasing the DNA concentration. Any change in the complex concentration due to each titration was negligible. The intrinsic binding constant, $\mathrm{K}_{\mathrm{b}}$ was determined through an earlier reported method [30].

\section{Emission spectroscopy}

Emission intensity measurements were carried out using a Carey Fluorescence Spectrophotometer 5000 at room temperature. Tris-HCl buffer was used as the control to make preliminary adjustments. Competitive binding experiments were performed in this same buffer. The [DNA]/[EB] ratio was kept at 1.10 and the concentration of $\mathbf{2}$ was varied. Fluorescence spectra of EB were measured using an excitation wavelength of $360 \mathrm{~nm}$ and the emission range was set between 440 and $750 \mathrm{~nm}$. To understand the binding strength magnitude of $\mathbf{2}$ with DNA, the linear Stern-Volmer equation (eq. 1) is applied [31]: see formula 1 in the supplementary files.

where $\mathrm{I}_{0}$ and I represent the fluorescence intensities in the absence and presence of 2 (quencher), respectively. $\mathrm{Q}$ is the concentration of $\mathbf{2}$. $\mathrm{K}_{\mathrm{sv}}$ is the quenching constant.

\section{Cyclic Voltammetry (CV) studies}


All electrochemical studies were performed using a $\mathrm{CH}$ Instrument Electrochemical analyzer in a single compartmental cell with a three-electrode configuration. This configuration is comprised of a Pt wire as the auxiliary electrode, a glassy carbon electrode as the working electrode, and $\mathrm{Ag} / \mathrm{AgCl}$ as the reference electrode. A 1:1 mixture of acetonitrile and Tris buffer ( $\mathrm{pH} 7.2)$ was used as the solvent, and $0.05 \mathrm{M}$ tetrabutylammonium perchlorate was used as the supporting electrolyte.

\section{Viscosity study}

Viscosity measurements were carried out using a 3156 viscometer (Q Glass Company Inc) as reported earlier [30]. In brief, the flow times were measured using a digital stopwatch. The CT-DNA was quantitated by absorbance at $260 \mathrm{~nm}$ using a NanoVue UV spectrophotometer. CT-DNA was held constant at $200 \mu \mathrm{M}$ and varying concentrations of $4,8,12,16,20,24,48,96$, and $200 \mu \mathrm{M}$ for complex 2 and EB were used. Mixtures of the CT-DNA and complex 2 or CT-DNA and EB were incubated for $30 \mathrm{~min}$ at room temperature. Relative viscosities for the CT-DNA in the presence and absence of complex 2 were calculated from the relation: $\eta \infty\left(t-t_{0}\right)$, where $t$ is the observed flow time of DNA solutions and $t_{o}$ is that of phosphate buffer alone. The data are reported as $\left(\eta / \eta_{0}\right)^{1 / 3}$ versus [complex 2]/[DNA], where $\eta$ is the viscosity of DNA in the presence of the complex 2 and $\eta_{0}$ is the viscosity of DNA alone [32].

\section{Cell culture and cytotoxicity assay}

\section{Pancreatic cancer cells (BxPC-3)}

BxPC-3 cells were maintained in RPMI-1640 medium supplemented with $10 \%$ FBS and $1 \%$ penicillin/streptomycin. Cells were cultured at $37^{\circ} \mathrm{C}$ in a humidified atmosphere supplied with $5 \% \mathrm{CO}_{2}$. After culturing for $36 \mathrm{~h}$, cells were treated with the tetranuclear rhenium complex 2 for $72 \mathrm{~h}$. Cell viability was performed using the MTT assay. Briefly, cells were washed with PBS three times and then incubated with $1 \mathrm{~mL}$ of MTT solution $\left(0.25 \mathrm{mg} / \mathrm{ml}\right.$ in PBS) for $4 \mathrm{~h}$ at $37^{\circ} \mathrm{C}$ in $5 \% \mathrm{CO}_{2}$ atmosphere. The medium was removed and $1 \mathrm{~mL}$ of $0.04 \mathrm{M} \mathrm{HCl}$ in absolute isopropanol was added to dissolve the MTT formazan. Absorbance of the formazan solutions were measured at $540 \mathrm{~nm}$. The percent viable cells were determined according to the following calculations:

$\%$ viable cells $=\left[\left(\mathrm{abs}_{\text {sample }}-\mathrm{abs}_{\text {blank }}\right) /\left(\mathrm{abs}_{\text {control }}-\mathrm{abs}_{\text {blank }}\right) \times 100\right.$

\section{Breast cancer cells (MCF-7 and MDA-MB-231)}

We have earlier reported a detailed cell culture and cytotoxicity assay using breast cancer cells [30]. The ER (+) MCF-7 breast cancer cell lines were maintained in MEM medium supplemented with insulin, FBS and Pen/Strep. Similarly, the ER (-) MDA-MB-231 breast cancer cell lines were maintained in DMEM medium supplemented with FBS and Pen / Strep. On day 1, the cell lines were trypsinized, suspended in proper medium to 25,000 cells $/ \mathrm{mL}$, and $40 \mu \mathrm{L}$ were aliquoted into 384 -well clear tissue culture plates for 1000 cells per well. On day 2, $0.5 \mu \mathrm{L}$ of the tetranuclear rhenium complex 2 diluted in DMSO was added with an equivalent amount of DMSO being added for the "DMSO control." The cells were incubated at 37 
${ }^{\circ} \mathrm{C}$ and $5 \% \mathrm{CO}_{2}$ until day 5 , or 72 -h post drug addition, at which time $4 \mu \mathrm{L}$ of Alamar blue reagent was added to each well including top the "DMSO control" wells. Plates were then incubated for an additional 2 $\mathrm{h}$ at $37^{\circ} \mathrm{C}$. After this time period, the fluorescence was read with at an excitation wavelength of $540 \pm 10$ $\mathrm{nm}$ and an emission wavelength of $590 \pm 10 \mathrm{~nm}$ on a multimode microplate reader. Percent fluorescence intensity of the DMSO control was determined from the measured relative fluorescence units. The $\mathrm{IC}_{50}$ was determined by nonlinear curve fitting to the dose-response curve.

\section{Lymphoma cells (U-937)}

U937 cells were grown in RPMI-1640 medium, supplemented with $10 \%(\mathrm{v} / \mathrm{v})$ heat in-activated FBS, $2 \mathrm{mM}$ L-glutamine, 10 units $/ \mathrm{ml}$ penicillin and $10 \mathrm{mg} / \mathrm{ml}$ streptomycin at $37{ }^{\circ} \mathrm{C}, 5 \% \mathrm{CO}_{2} / 95 \%$ air in $75-\mathrm{mL}$ flasks. These cells were screened on a regular basis for the presence of mycoplasma and were found to be negative. Fresh medium was added twice weekly. The cell density was kept at $2-8 \times 10^{5}$ cells per $\mathrm{ml}$. A hemocytometer was used to count cells and cells were subsequently resuspended to the desired concentration. When the growth reached approximately $10^{6} \mathrm{cells} / \mathrm{ml}$, the cells were removed from the flask, centrifuged, the pellet was washed with RPMI-1640 and distributed into wells of a 24-well plate at cell densities of $5 \times 10^{5}$ /well. Cell treatment with the rhenium complex 2 and viability assays were carried out according to the procedure described above for pancreatic cancer cells.

\section{Results And Discussion}

\section{Synthesis and characterization}

We previously reported the synthesis and characterization of the tetranuclear rhenium complex 2 [12]. The molecular structure of 2 is shown in Fig. 1. Both rhenium atoms ( $\operatorname{Re} 1$ and $\operatorname{Re} 2)$ in the cation are in +1 states and are connected through a bridging hydride ion. Both rhenium atoms ( $R e 3$ and $\operatorname{Re} 4$ ) in the anion are also in +1 oxidation states and are connected through three bridging pentyl alkoxide ions.

\section{DNA-binding studies}

The electronic absorption spectrum of 2 exhibits intense absorptions centered at 235 and $280 \mathrm{~nm}$ which are assigned to intraligand $\pi-\pi^{\star}$ transitions because similar absorptions are observed for the uncoordinated neocuproine ligand. The lower-energy absorption shoulders in the range $350-425 \mathrm{~nm}$ are assigned to spin-allowed metal-to-ligand charge-transfer (MLCT) $d \pi \rightarrow \pi^{\star}$ transitions. When a complex binds with DNA through intercalation, it usually results in hypochromism (reduction in absorbance) and bathochromism (red shift) due to strong stacking interaction between aromatic chromophore and the base pairs of DNA. Addition of increasing amounts of CT-DNA to a fixed concentration of 2 resulted in both hypochromism and bathochromism for the band at $280 \mathrm{~nm}$ (see Fig. 2) suggesting that the complex binds to DNA through intercalation. The intrinsic binding constant $\mathrm{K}_{b}$ of the complex 2 to DNA was determined by monitoring the changes of absorbance at $280 \mathrm{~nm}$ with increasing concentration of DNA 
(see Fig. 2) and plotting [DNA]/( $\left.\mathbb{\Xi}_{0}-\mathbb{\bigotimes}_{\mathrm{f}}\right)$ vs. [DNA] (Fig. 2 inset). The calculated $\mathrm{K}_{\mathrm{b}}$ value of $5.22 \times 10^{4}$ is significantly lower than that of classical DNA intercalator $E B\left(K_{b}=1.4 \times 10^{6} \mathrm{M}^{-1}\right)$ [33].

To further ascertain the mode of interaction of 2, the ethidium bromide (EB) displacement assay was carried out [34]. The intrinsic fluorescence intensity of DNA is very low, and that of EB in Tris buffer is also not high due to quenching by the solvent molecules. However, EB emits intense fluorescence in the presence of DNA, due to its strong intercalation between the adjacent DNA pairs. Thus, EB can be used to probe the interaction of $\mathbf{2}$ with DNA. The emission spectra of EB bound to DNA in the presence of $\mathbf{2}$ is shown in Fig. 3. The addition of 2 to DNA pretreated with EB causes obvious reduction in emission intensity at $608 \mathrm{~nm}$, indicating that 2 competes with EB in binding to DNA. This observation is often the characteristic of intercalation [35]. The quenching constant, $\mathrm{K}_{\mathrm{sv}}\left(1.12 \times 10^{4}\right)$ is determined by plotting $\mathrm{I}_{0} / \mathrm{I}$ versus the concentrations of $\mathbf{2}$ (see Fig. 3 inset). The apparent binding constant $\mathrm{K}_{\mathrm{app}}$ is calculated according to eq. 2 : see formula 2 in the supplementary files.

$\mathrm{K}_{\mathrm{EB}}=1.0 \times 10^{7} \mathrm{M}^{-1},[\mathrm{~EB}]=1.24 \mu \mathrm{M}$ and [complex 2] = concentration of complex 2 at a $50 \%$ reduction of the fluorescence intensity of EB [34]. In Stern-Volmer equation (eq. 1), I becomes $\mathrm{I}_{0} / 2$ at a $50 \%$ reduction of the fluorescence intensity. Thus, [complex 2] becomes $1 / K_{s v}$. As a result, $K_{a p p}$ equals to $K_{E B}[E B] \times K_{s v}$ or $1.0 \times 10^{5}$. This is significantly lower than the $K_{E B}$ value for $E B$.

The cyclic voltammograms of 2 in the oxidation region (A) and the reduction region (B) in the absence (black) and presence (red) of DNA are shown in Fig. 4. The oxidation peak around 1.6 V was shifted slightly toward more oxidizing direction $(\mathrm{A})$ while the two reduction peaks between 1.3 and $1.5 \mathrm{~V}$ were unchanged $(B)$ in the presence of DNA. Since oxidation peaks are metal-centered and reduction peaks are ligand-based, the observations here suggest some kind of interactions between the complex and DNA; further, the interaction may be at or close to the metal site, possibly through electrostatic attraction, while the ligands are farther away from DNA with no influence from the DNA interaction.

Viscosity measurement is regarded as the least ambiguous and most precise method of studying the binding mode of metal complexes with DNA in the absence of X-ray crystallography and NMR spectroscopy. It is suggested that an intercalative binding causes a significant increase in DNA viscosity due to the lengthening of the DNA helix.

As illustrated in Fig. 5, upon increasing the concentrations of $\mathbf{2}$, the relative viscosities of $\mathbf{2}$ increase less steadily than those of EB. These results suggest that the complex 2 less strongly intercalates between the base pairs of DNA.

\section{Cytotoxicity Studies}

Pancreatic cancer cells (BxPC-3). The ability to inhibit the cell growth by 2 was evaluated in vitro against BxPC-3 human pancreatic cancer cell lines. An $\mathrm{IC}_{50}$ value of $0.22 \mu \mathrm{M}$ was obtained through MTT assay (see Fig. 6). In combination with other anticancer drugs both cisplatin and oxaliplatin are used as 
combination drugs. The leading pancreatic cancer drug FOLFIRINOX is a mixture of folinic acid, 5fluorouracil, irinotecan and oxaliplatin. The $\mathrm{IC}_{50}$ values of cisplatin and oxaliplatin against BxPC-3 are 11 $\mu \mathrm{M}$ [36] and $4 \mu \mathrm{M}$ [37] respectively. The values are relatively high compared to the $\mathrm{IC}_{50}$ value of 2 . Previously we demonstrated that tricarbonyl rhenium (I) polypyridyl complexes are very active on BxPC-3 pancreatic cancer cell lines $\left(\mathrm{IC}_{50}<5 \mu \mathrm{M}\right)[38,39]$. Recently several other tricarbonyl rhenium (I) complexes have been reported to be highly cytotoxic $\left(\mathrm{IC}_{50}\right.$ in the range $\left.4-9 \mu \mathrm{M}\right)$ against a panel of pancreatic cancer cell lines [23,24]. Cytotoxicity of a few metal complexes against numerous pancreatic cancer cell lines are also known [40-42].

Breast cancer cells (MCF-7 and MDA-MB-231). The anticancer activity of 2 was investigated in vitro on MCF-7 and MDA-MB-231 cells. The IC ${ }_{50}$ values of $0.298 \pm 0.234$ and $0.948 \pm 0.206 \mu \mathrm{M}$ on MCF-7 and MDAMB-231, respectively were obtained from alamar blue assays (see Fig. 7 and 8 ). The $\mathrm{IC}_{50}$ values of cisplatin on MCF-7 and MDA-MB-231 were reported as $9.740 \pm 0.537$ and $43.600 \pm 7.071 \mu \mathrm{M}$ respectively [43]. 2 is highly potent on both cell lines. Similar low $\mathrm{IC}_{50}$ values were previously observed in several rhenium [18-25,44] and ferrocifen complexes [45-47].

Lymphoma cells (U-937). The inhibition of cell growth by 2 was evaluated on U-937 lymphoma cells. The $\mathrm{IC}_{50}$ value was derived from MTT assay which is shown in Fig. 9. The IC-50 value of $0.3 \mu \mathrm{M}$ was observed for 2 , whereas in cisplatin, an $\mathrm{IC}_{50}$ value of $2.8 \mu \mathrm{M}$ [48] was observed. The $\mathrm{IC}_{50}$ values of structurally similar rhenium complexes for suspension and non-suspension tumor cells are also known [49-51].

\section{Summary And Outlook}

We explored the DNA binding studies through UV-vis and fluorescence titrations, cyclic voltammetry and viscosity measurements. Both UV and fluorescence titrations indicate that $\mathbf{2}$ binds to DNA intercalatively. The values of the binding constants $K_{b}$ are low in comparison with the $K_{b}$ value of EB with DNA. The study through cyclic voltammetry suggests a very poor or no binding. However, viscosity experiments suggest moderate binding through intercalation. The compound $\mathbf{2}$ is a salt. Therefore, this cationic compound has other possibilities to interact with DNA. The positively charged species may be attracted to the negatively charged DNA-phosphate backbone by electrostatic attraction. There could be some hydrophobic interactions with the major or minor groove. In fact, we have observed that the majority of tricarbonyl Re (I) polypyridyl complexes of the type, fac-(CO) $)_{3}$ (Polypyridyl)ReX interact with DNA through minor groove [30].

The organometallic salt $\mathbf{2}$ is highly active on pancreatic and breast cancer and lymphoma cells. To the best of our knowledge, no such metal complexes like 2 are known to be highly potent on pancreatic cancer cells. It is known that rhenium complexes are less toxic than platinum metal complexes. One of the ingredients of FOLFIRINOX is oxaliplatin which may be substituted with $\mathbf{2}$ to yield a better pancreatic cancer drug. Pancreatic cancer has been the second leading cause of cancer-related deaths in the USA. 
Due to its chemoresistance, it has been designated as a recalcitrant cancer. Also, $\mathbf{2}$ may find applications in the treatment of breast and lymphoma cancers.

\section{Declarations}

\section{Acknowledgements}

The work was supported, in part, with funds from the Center for Biomolecular Therapeutics (CBT) at the University of Maryland, School of Medicine (from DJW). The research was also partially supported by the NIH Grant No. 5R25GM0058904 to AJW at Morgan State University and T34 GM100831-08 to HNB at Elizabeth City State University. PCM acknowledges the ASCEND grant (NIH Grant No. UL1GM118973) at Morgan State University for partial support of this work.

\section{Author Contributions}

Conceptualization: DJW, SKM, SKP, HNB

Synthesis: CCK, BYV, AJW

Characterizations: AJW, SKM

Cytotoxicity studies: PTW, DJW, FHS, SKP, KJ, HNB

X-ray structure determinations: $\mathrm{DMH}$

DNA-binding studies: CCK, BYV, YZ, FAA, SG, PCM

Writing - Original draft: SKM, SKM, HNB

Reviewing - editing: AJW, DJW, PCM, DMH

Final document: SKM

\section{Compliance with Ethical Standards}

Conflict of Interest: The authors have no conflict to declare in this research

\section{Availability of data and materials}

CCDC 1908192 contains the supplementary crystallographic data for the reduced dirhenium complex. These data can be obtained free of charge via http://www.ccdc.cam.ac.uk/data_request/cif, or by emailing data_request@ccdc.cam.ac.uk, or by contacting the Cambridge Crystallographic Data Centre, 12 Union Road, Cambridge CB2 1EZ, UK; Fax: +44-1223-336033. 


\section{References}

1. Dombek BD (1983) Metal hydrides in homogeneous catalytic reduction of carbon monoxide. Ann NY Acad Sci 415:176-190.

2. Mandal SK, Ho DM, Orchin M (1993) Reactions of electrophiles with manganese(I) and rhenium(I) alkoxide complexes: reversible absorption of atmospheric $\mathrm{CO}_{2}$. Organometallics 12:1714 -1719.

3. Mandal SK, Ho DM, Orchin M (1991) A convenient synthesis of the manganese and rhenium alkoxides and phenoxides fac-(CO) $)_{3}(\mathrm{dppe}) \mathrm{MOR}\left(\mathrm{R}=\mathrm{CH}_{3}, \mathrm{C}_{2} \mathrm{H}_{5}, \mathrm{C}_{6} \mathrm{H}_{5}\right.$; dppe $=\mathrm{I}, 2-$ Bis(diphenylphosphino)ethane). X-ray structure of fac- $(\mathrm{CO})_{3}(\mathrm{dppe}) \mathrm{ReOC}_{6} \mathrm{H}_{5}$. Inorg Chem 30:2244 $-2248$.

4. O'keiffe LS, Mitchell AC, Becker TM, Ho DM, Mandal SK (2000) Reactions of $\left[(C O)_{3}(P-P) M n\right]_{2}$ with primary alcohols, where, $\mathrm{P}-\mathrm{P}$ is dppe $\left\{\mathrm{Ph}_{2} \mathrm{P}\left(\mathrm{CH}_{2}\right)_{2} \mathrm{PPh}_{2}\right\}$, dppp $\left\{\mathrm{Ph}_{2} \mathrm{P}\left(\mathrm{CH}_{2}\right)_{3} \mathrm{PPh}_{2}\right\}$, dppb $\left\{\mathrm{Ph}_{2} \mathrm{P}\left(\mathrm{CH}_{2}\right)_{4} \mathrm{PPh}_{2}\right\}$, dpppe $\left\{\mathrm{Ph}_{2} \mathrm{P}\left(\mathrm{CH}_{2}\right)_{5} \mathrm{PPh}_{2}\right\}$, dtpe $\left\{(p \text {-tol })_{2} \mathrm{P}\left(\mathrm{CH}_{2}\right)_{2} \mathrm{P}(p \text {-tol })_{2}\right\}$, or dcpe $\left\{(\text { Chex })_{2} \mathrm{P}\left(\mathrm{CH}_{2}\right)_{2} \mathrm{P}(\text { Chex })_{2}\right\}$. Synthesis of fac-(CO) $)_{3}(\mathrm{P}-\mathrm{P}) \mathrm{MnH}$ and the $\mathrm{X}$-ray structure of fac$(\mathrm{CO})_{3}(\mathrm{dtpe}) \mathrm{MnH}$. J Organomet Chem 613:13-18.

5. Mandal SK, Feldman J, Orchin M (1994) A New route to manganese and rhenium carbonyl tetrafluoroborate salts and an improved procedure for preparing their precursor hydrides. J Coord Chem 33:219 -221.

6. Orchin M, Mandal SK, Feldman J, Lee W-Z, Darensbourg DJ (1998) Tricarbonyl(hydrido)[1,2bis(diphenylphosphino)ethane]manganese as precursor to labile site derivatives. Inorg Synth 32:298 $-302$.

7. Kimari DM, Duzs-Moore AM, Cook J, Miller KE, Budzichowski TA, Ho DM, Mandal SK (2005) One-pot synthesis and the X-ray structures of rhenium(I) diphosphine hydrides, fac-(CO) $)_{3}(\mathrm{P}-\mathrm{P}) \mathrm{ReH}[\mathrm{P}-\mathrm{P}=$ dppp, dppb, and dppfe]. Inorg Chem Commun 8:14 -17.

8. Johnson K, Frazier T, Becker TM, Miller K, Ho DM, Krause-Bauer J, Mandal SK (2001) One-pot synthesis of manganese $(I)$ and rhenium(I) alkylcarbonato complexes, fac-(CO) ${ }_{3}(\mathrm{dppp}) \mathrm{MOC}(\mathrm{O}) \mathrm{OR}$. Possible trapping of intermediate diphosphine dimers, $\left[(\mathrm{CO})_{3}(\mathrm{dppp}) \mathrm{M}\right]_{2}$. Inorg Chem Commun 4:602 -05 .

9. Orsa DK, Haynes GK, Pramanik SK, Iwunze MO, Greco GE, Krause JA, Ho DM, Williams AL, Hill DA, Mandal SK (2007) Synthesis, characterization, and fluorescence and cytotoxicity studies of a tetrarhenium molecular rectangle. Inorg Chem Commun 10:821 -824.

10. Vieyra FEM, Cattaneo M, Fagalde F, Bozoglián F, Llobet A, Katz NE (2011) Influence of the linker length on the host-guest properties of alkoxy-and polypyridine-bridged molecular rectangles of formulae $\left\{\left[\operatorname{Re}(\mathrm{CO})_{3}\left(\mathrm{OC}_{5} \mathrm{H}_{11}\right)\right]_{4}(\mathrm{~L})_{2}\right\}$, with $\mathrm{L}=4$-pyridinealdazine and 4,4'-azobis(pyridine). Inorg Chim Acta 374:247-252.

11. See Supplementary Information for its structure. 
12. Orsa DK, Nettles CR, Pramanik SK, Iwunze MO, Greco GE, Krause JA, Mandal SK (2009) Cytotoxic effects of rhenium (I) carbonyl complexes on prostate cancer cell lines, in: A.T. Meridith (Ed.), Handbook of Prostate Cancer Cell Research: Growth, Signalling, Survival, Nova Science Publishers, Inc., New York, 323-362.

13. Oliveira CG, Romero-Canelón I, Coverdale JPC, Maia PIS, Clarkson GJ, Deflon V M, Sadler PJ (2020) Novel tetranuclear Pd" and Pt" anticancer complexes derived from pyrene thiosemicarbazones. Dalton Trans 49:9595 -9604.

14. Sun B, Sundaraneedi MK, Southam HM, Poole RK, Musgrave IF, Keene FR, Collins JG (2019) Synthesis and biological properties of tetranuclear ruthenium complexes containing the bis[4(4'methyl-2,2'-bipyridyl)]-1,7-heptane ligand, Dalton Trans. 48:14505-14515.

15. Aouaidjia F, Messai A, Siab R, Ayesh Al (2017) A new tetranuclear copper(II)complex using a Schiff base ligand: synthesis, structural, and magnetic studies. Polyhedron 133:257- 263.

16. Lin Y-Y, Lai S-W, Che C-M, Cheung K-K, Zhou ZY (2002) Luminescent tetranuclear silver(I) arylacetylide complexes bearing tricyclohexylphosphine ligands: synthesis, molecular structures, and spectroscopic comparison with gold(I) and copper(I) arylacetylides, Organometallics 21:2275 -2282.

17. Sougoule AS, Balde CA, Keita N, Xiao X, Han X, Liang J, Zhu D (2015) A novel tetranuclear organotin(IV) carboxylate with chain structure: synthesis, crystal structure, and characterizations, Heteroat Chem 26:382 -390.

18. See: Leonidova A, Gasser G, Underestimated potential of organometallic rhenium complexes as anticancer agents, ACS Chem. Biol. 2014, 9, 2180-2193 and the references cited therein.

19. Collery P, Veena V, Harikrishnan A, Desmaele D (2019) The rhenium(I)- diselenoether anticancer drug targets ROS, TGF- $\beta 1$, VEGF-A, and IGF-1 in an in vitro experimental model of triple-negative breast cancers. Invest New Drugs 37: 973 - 983. https://doi.org/10.1007/s10637-019-00727-1.

20. He L, Pan Z-Y, Qin W-W, Li Y, Tan C-P, Mao Z-W (2019) Impairment of the autophagy-related lysosomal degradation pathway by an anticancer rhenium(I) complex. Dalton Trans 48:4398-4404.

21. See: Liew HS, Mai C-W, Zulkefeli M, Madheswaran T, Kiew LV, Delsuc N, Low ML (2020) Recent Emergence of Rhenium(I) Tricarbonyl complexes as photosensitisers for cancer therapy. Molecules 25: 4176 and the references cited therein. doi:10.3390/molecules 25184176

22. See: Bauer EB, Haase AA, Reich RM, Crans DC, Kühn FE (2019) Organometallic and coordination rhenium compounds and their potential in cancer therapy. Coord Chem Rev 393:79-117 and the references cited therein.

23. Simpson PV, Casari I, Paternoster S, Skelton BW, Falasca M, Massi M (2017) Defining the anti-cancer activity of tricarbonyl rhenium complexes: induction of $\mathrm{G} 2 / \mathrm{M}$ cell cycle arrest and blockade of Aurora-A kinase phosphorylation. Chem Eur J 23:6518 -6521.

24. Domenichini A, Casari I, Simpson PV, Desai NM, Chen L, Dustin C, Edmands JS, Vliet A, Mohammadi M, Massi M, Falasca M (2020) Rhenium Nheterocyclic carbene complexes block growth of aggressive cancers by inhibiting FGFR- and SRC-mediated signaling. J Exp Clin Cancer Res 39:276 https://doi.org/10.1186/s13046-020-01777-7.

Page 11/26 
[25] Collery P, Desmaele D, Vijaykumar V (2019) Design of rhenium compounds in

targeted anticancer therapeutics. Curr Pharm Des 25:3306 -3322.

[26] Delasoie J, Pavic A, Voutier N, Vojnovic S, Crochet A, Nikodinovic-Runic J, Zobi F

(2020) Identification of novel potent and non-toxic anticancer, anti-angiogenic and

antimetastatic rhenium complexes against colorectal carcinoma. Eur J Med

Chem 204:112583 https://doi.org/10.1016/j.ejmech.2020.112583

[27] Capper S, Packman H, Rehkämper M (2020) Rhenium-based complexes and in

vivo testing: a brief history miles. ChemBioChem 21:2111 -2115.

[28] Marker SC, King AP, Swanda RV, Vaughn B, Boros E, Q S-B, Wilson JJ (2020)

Exploring Ovarian Cancer Cell Resistance to Rhenium Anticancer Complexes.

Angew Chem Int Ed 59:13391 -13400.

[29] Pan Z-Y, Cai D-H, He L (2020) Dinuclear phosphorescent rhenium(I) complexes as potential anticancer and photodynamic therapy agents. Dalton Trans 49:11583- 
11590.

[30] Wilder PT, Weber DJ, Winstead A, Parnell S, Hinton TV, Stevenson M, Giri D,

Azemati S, Olczak P, Powell BV, Odebode T, Tadesse S, Zhang Y, Pramanik SK,

Wachira JM, Ghimire S, McCarthy P, Barfield A, Banerjee HN, Chen C, Golen JA,

Rheingold AL, Krause JA, Ho DM, Zavalij PY, Shaw R, Mandal SK (2018)

Unprecedented anticancer activities of organorhenium sulfonato and carboxylato

complexes against hormone-dependent MCF-7 and hormone-independent triple-

negative MDA-MB-231 breast cancer cells. Mol Cell Biochem 441:151 -163.

[31] Stern O, Volmer M (1919) über die Abklingzeit der Fluoreszenz. Z Phys 20:183

$-188$.

[32] Cohen G, Eisenberg H (1969) Viscosity and sedimentation study of sonicated DNA-proflavine complexes. Biopolymers 8:45 -55. 
[33] Waring MJ (1965) Complex formation between ethidium bromide and nucleic

Acids. J Mol Biol 13:269 -282.

[34] Jiang M, Li Y-T, Wu Z-Y, Liu Z-Q, Yan C-W (2009) Synthesis, crystal structure, cytotoxic activities and DNA-binding properties of new binuclear copper(II) complexes bridged by N,N'-bis(N-hydroxyethylaminoethyl)oxamide. J Inorg Biochem 103:833 -844.

[35] Anbu S, Kandaswamy M, Suthakaran P, Murugan V, Varghese B (2009) Structural, magnetic, electrochemical, catalytic, DNA binding and cleavage studies of new macrocyclic binuclear copper(II) complexes. J Inorg Biochem 103:401 -410.

[36] Biancalana L, Pratesi A, Chiellini F, Zacchini S, Funaioli T, Gabbiani C, Marchetti F (2017) Ruthenium arene complexes with triphenylphosphane ligands: cytotoxic activity towards pancreatic cancer cells, interaction with model proteins, and critical 
effect of ethacrynic acid substitution. New J Chem 41:14574 -14588.

[37] Raveendran R, Braude JP, Wexselblatt E, Novohradsky V, Stuchlikova O, Brabec

V, Gandin V, Gibson D (2016) Pt(IV) derivatives of cisplatin and oxaliplatin with

phenylbutyrate axial ligands are potent cytotoxic agents that act by several

mechanisms of action. Chem Sci 7:2381 -2391.

[38] Banerjee HN, Boston A, Barfield A, Stevenson M, Sarkar FH, Giri D, Winstead A,

Krause JA, Mandal SK (2016) A study of the effects of novel rhenium compounds

on pancreatic and prostate cancer cell lines. Int J Sci Res 5: 481-483.

[39] Mbagu MK, Kebulu DN, Winstead A, Pramanik SK, Banerjee HN, Iwunze MO,

Wachira JM, Greco GE, Haynes GK, Sehmer A, Sarkar FH, Ho DM, Pike RD,

Mandal SK (2012) Fac-tricarbonyl(pentylcarbonato)(a-diimine)rhenium complexes:

one-pot synthesis, characterization, fluorescence studies, and cytotoxic activity 
against human MDA-MB-231 breast, $\mathrm{CCl}-227$ colon and BxPC-3 pancreatic

carcinoma cell lines. Inorg Chem Commun 21: 35-38.

[40] Han J, Liu L, Yue X, Chang J, Shi W, Hua Y (2013) A binuclear complex constituted

by diethyldithiocarbamate and copper(I) functions as a proteasome activity inhibitor

in pancreatic cancer cultures and xenografts. Toxicol Appl Pharmacol 273:477-483.

[41] Palepu NR, Adhikari S, Premkumar J R, Verma AK, Shepherd SL, Phillips RM, Kaminsky W, Kollipara MR (2016) Half-sandwich ruthenium, rhodium and iridium complexes featuring oxime ligands: structural studies and preliminary investigation of in vitro and in vivo anti-tumour activities. Appl Organomet Chem 31: e3640.

https://doi.org/10.1002/aoc.3640

[42] Kowalski S, Wyrzykowski D, Hac S, Rychlowski M, Radomski MW, Inkielewicz-

Stepniak I. (2019) New oxidovanadium(IV) coordination complex containing 2- 
methylnitrilotriacetate ligands induces cell cycle arrest and autophagy in human

pancreatic ductal adenocarcinoma cell lines. Int J Mol Sci 20: 261.

doi:10.3390/ijms20020261

[43] Suntharalingam K, Awuah SG, Bruno PM, Johnstone TC, Wang F, Lin W, Zheng, Y-R, Page JE, Hemann MT, Lippard SJ (2015) Necroptosis-inducing rhenium(V) oxo complexes. J Am Chem Soc 137:2967 -2974.

[44] Lee LC-C, Leung K-K, Lo KK-W (2017) Recent development of luminescent rhenium(I) tricarbonyl polypyridine complexes as cellular imaging reagents, anticancer drugs, and antibacterial agents. Dalton Trans 46:16357 -16380.

[45] Pigeon P, Top S, Vessières A, Huché M, Görmen M, El Arbi M, Plamont M-A, McGlinchey MJ, Jaouen G (2011) A new series of ferrocifen derivatives, bearing two aminoalkyl chains, with strong antiproliferative effects on breast cancer cells.

New J Chem 35:2212 -2218.

[46] Jaouen G, Vessières A, Top S (2015) Ferrocifen type anticancer drugs. Chem Soc

$\operatorname{Rev} 44: 8802-8817$.

[47] Wang Y, Pigeon P, Top S, McGlinchey MJ, Jaouen G (2015) Organometallic 
antitumor compounds: ferrocifens as precursors to quinone methides, Angew Chem Int Ed 54:10230 -10233.

[48] Strese S, Fryknäs M, Larsson R, Gullbo J (2013) Effects of hypoxia on human cancer cell line chemosensitivity. BMC Cancer 13: 331. https://doi.org/10.1186/1471-2407-13-331

[49] Yan YK, Cho SE, Shaffer KA, Rowell JE, Barnes BJ, Hall IH (2000) Cytotoxicity of rhenium(I) alkoxo and hydroxo carbonyl complexes in murine and human tumor cells. Pharmazie 55: 307-313.

[50] Wang W, Yan YK, Hor TSA, Vittal JJ, Wheaton JR, Hall IH (2002) Synthesis, X-ray structures, and cytotoxicity of rhenium(I) carbonyl 2-(dimethylamino)ethoxide complexes. Polyhedron 21:1991 -1999.

[51] Zhang J, Vittal JJ, Henderson W, Wheaton JR, Hall IH, Hor TSA, Yan YK (2002) Tricarbonylrhenium(I) complexes of phosphine-derivatized amines, amino acids and a model peptide: structures, solution behavior and cytotoxicity $\mathrm{J}$ Organomet 
Chem 650: 123-132.

Figures

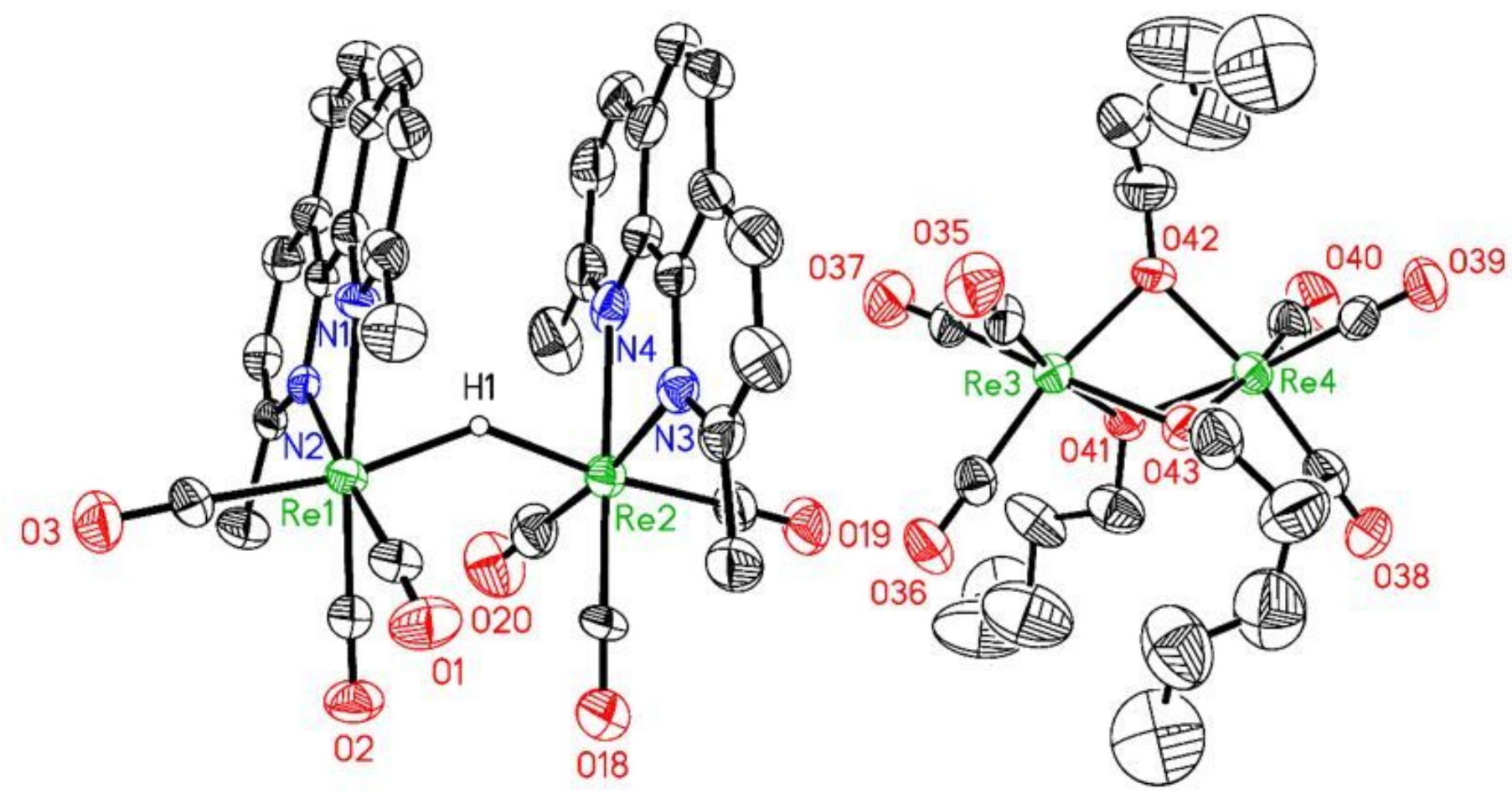

Figure 1

Views of the $[\operatorname{Re}(\mu-H) \operatorname{Re}]+$ cation (left) and[ $\operatorname{Re}(\mu-\mathrm{OR}) 3 \operatorname{Re}]$ - anion (right) in the X-ray structure of 2. 


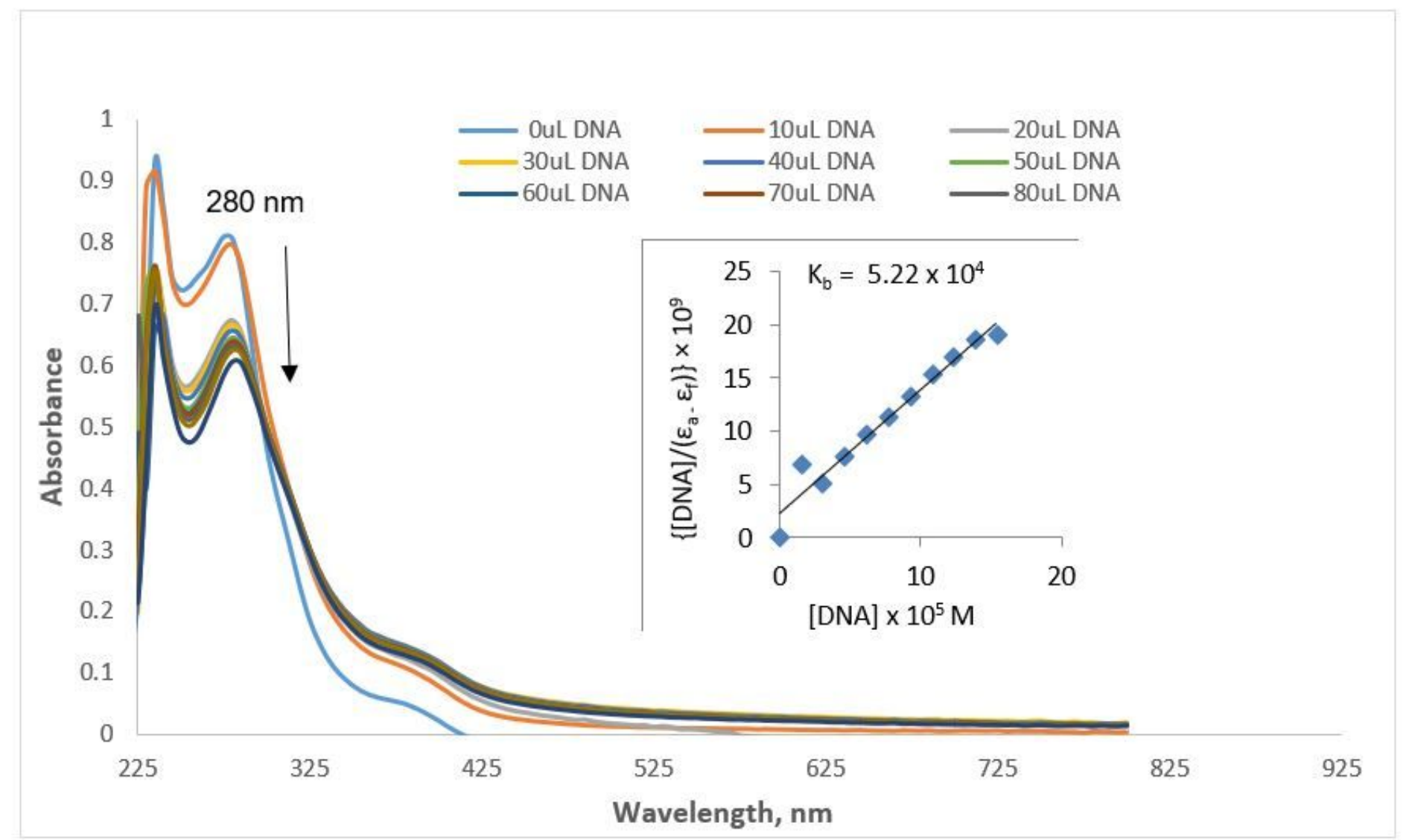

Figure 2

Absorption spectra for the titration of $25 \mu \mathrm{M}$ of 2 in the absence and presence of varied amounts of DNA. Stock [DNA] $=1693 \mu \mathrm{M}$. Inset: [DNA]/(囚0 -邓f) vs. [DNA]. 


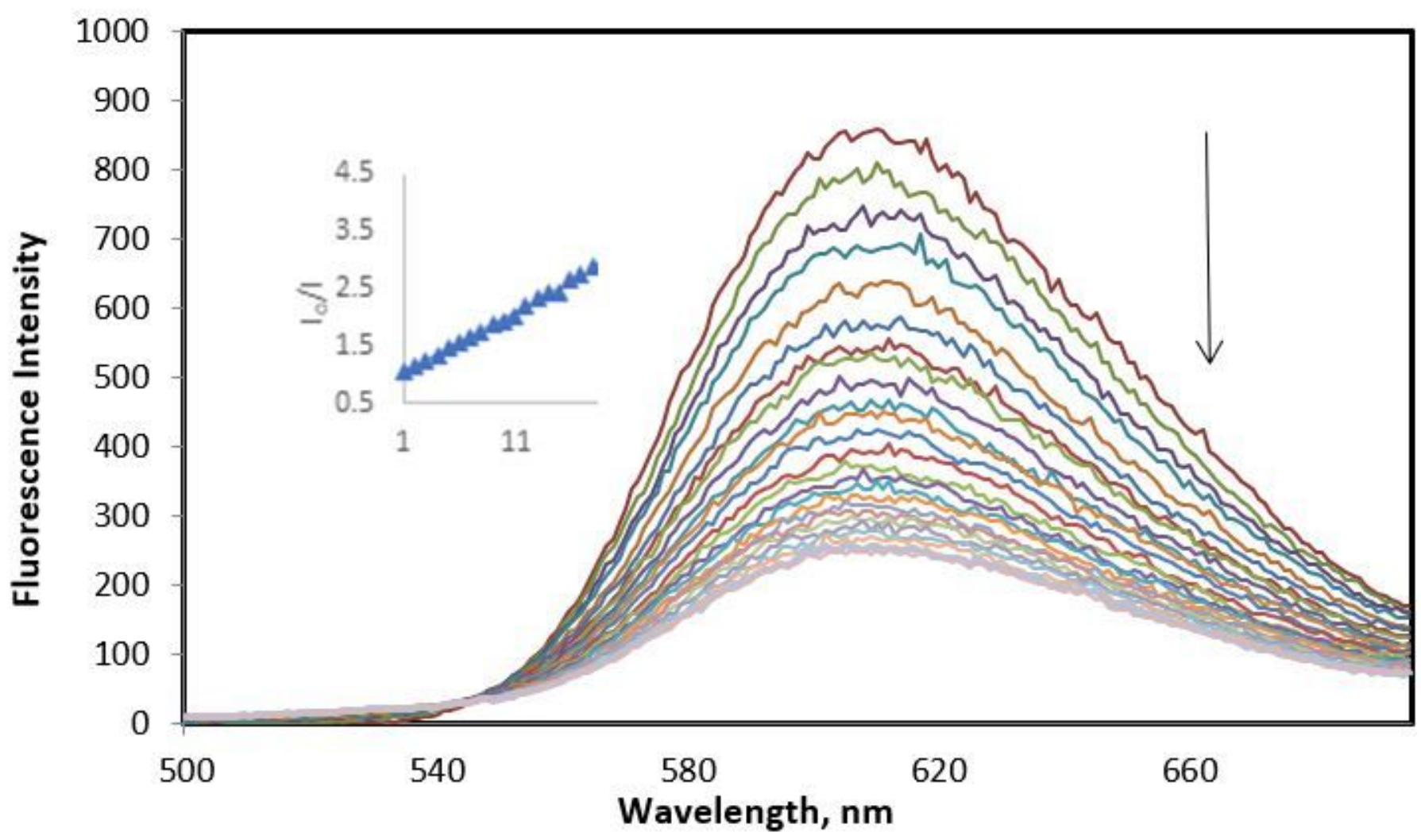

Figure 3

Emission spectra of the DNA-EB system upon titration of 2 in Tris- $\mathrm{HCl}$ buffer saline at $\mathrm{pH}=7.2$ at $25 \mathrm{oC}$. Arrow shows the change upon the increasing the concentration of 2. Inset - In the quenching plot of lo/I vs. [complex], ksv of complex is given by the slope. The ksv value for the $\operatorname{Re}(I)$ complex is $1.12 \times 104$ $(\mathrm{R}=0.9975)$. 

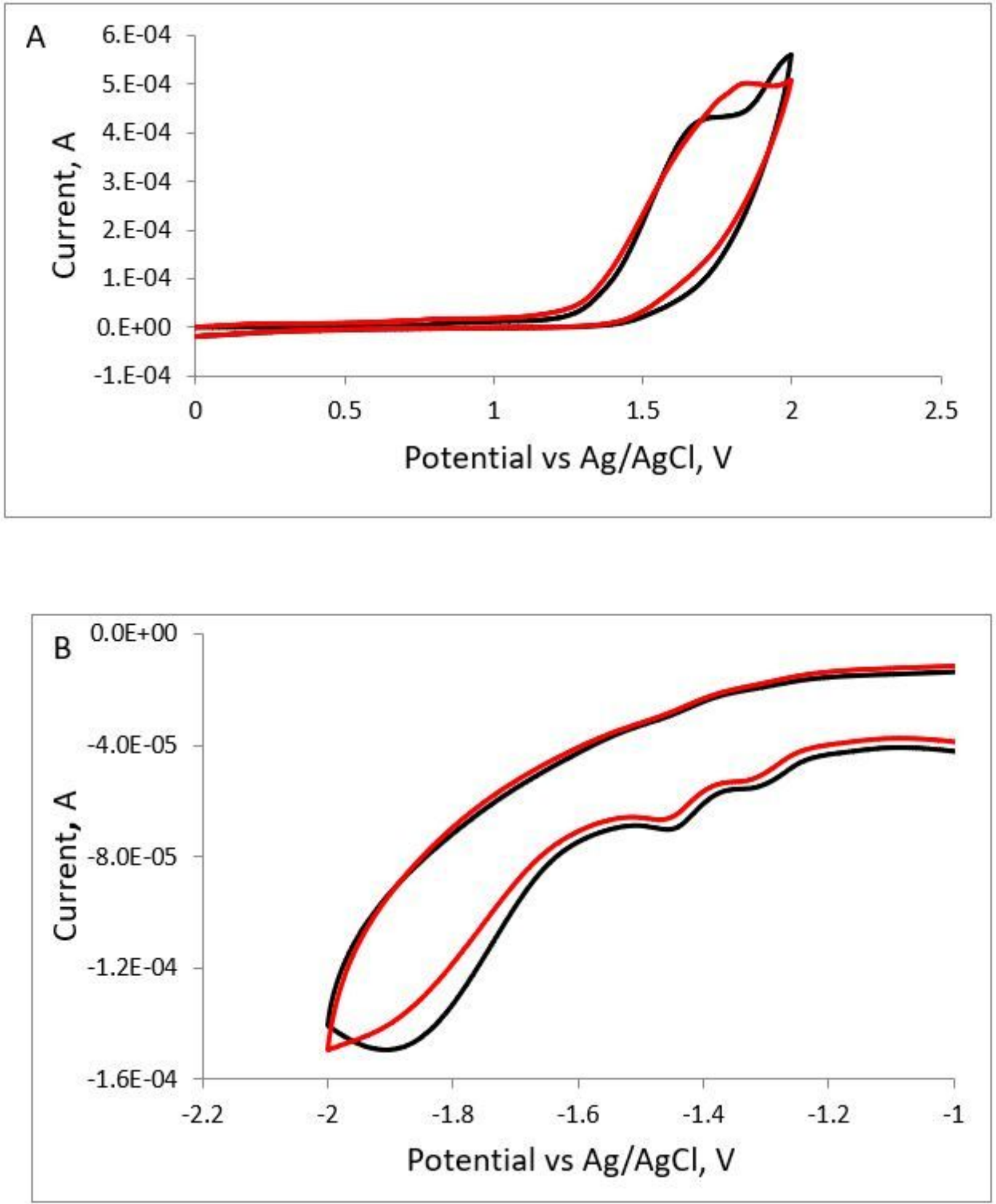

Figure 4

Cyclic voltammogram of 2 in the oxidation region (A) and reduction region (B) In the absence of DNA (black) and presence of DNA (B) 


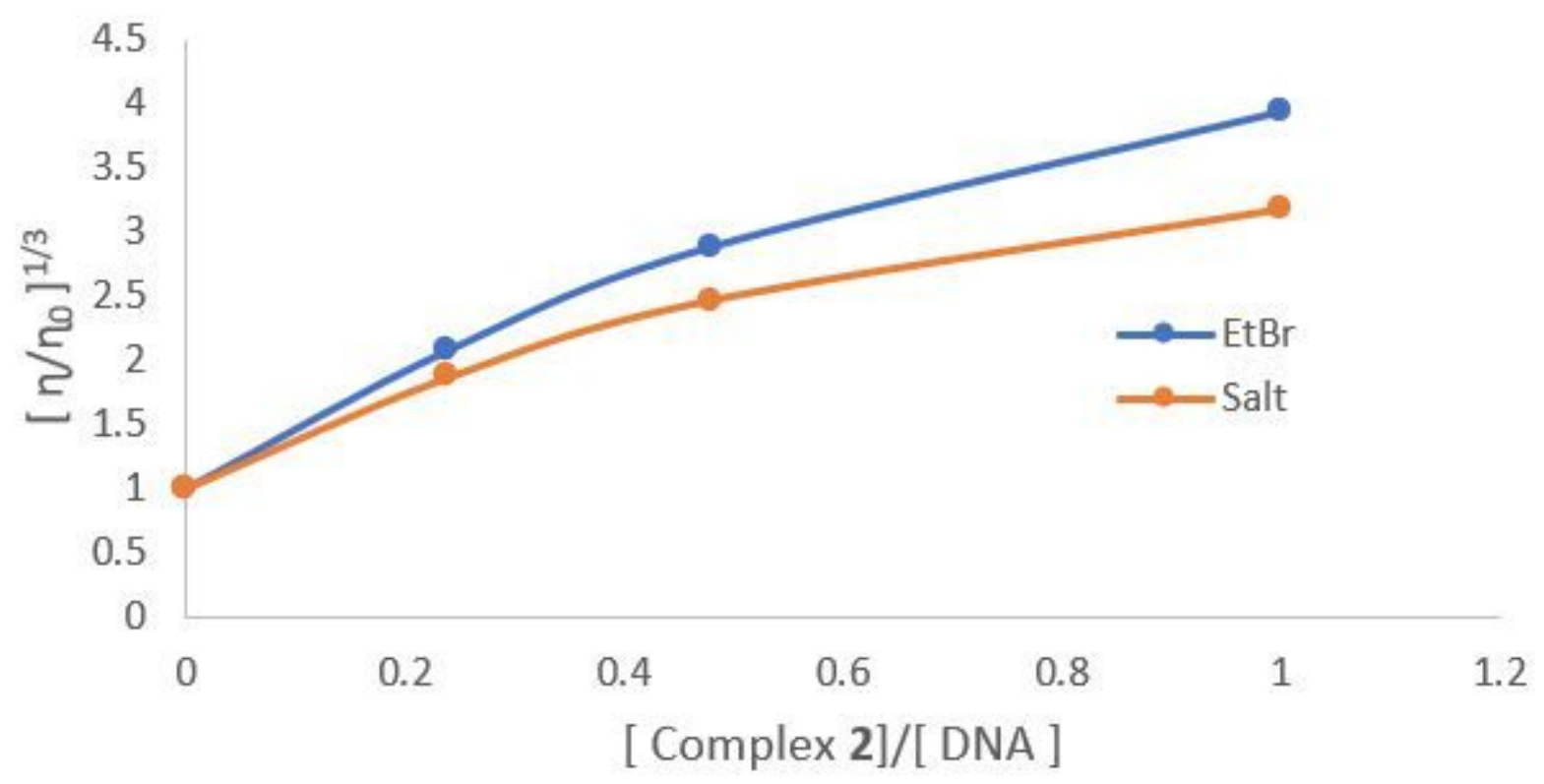

Figure 5

Effect of increasing amount of salt 4 and EB (or EtBr) on the relative viscosity CT-DNA at 298 K, [DNA] = $0.2 \mathrm{mM}$.

\section{BxPC-3}

120

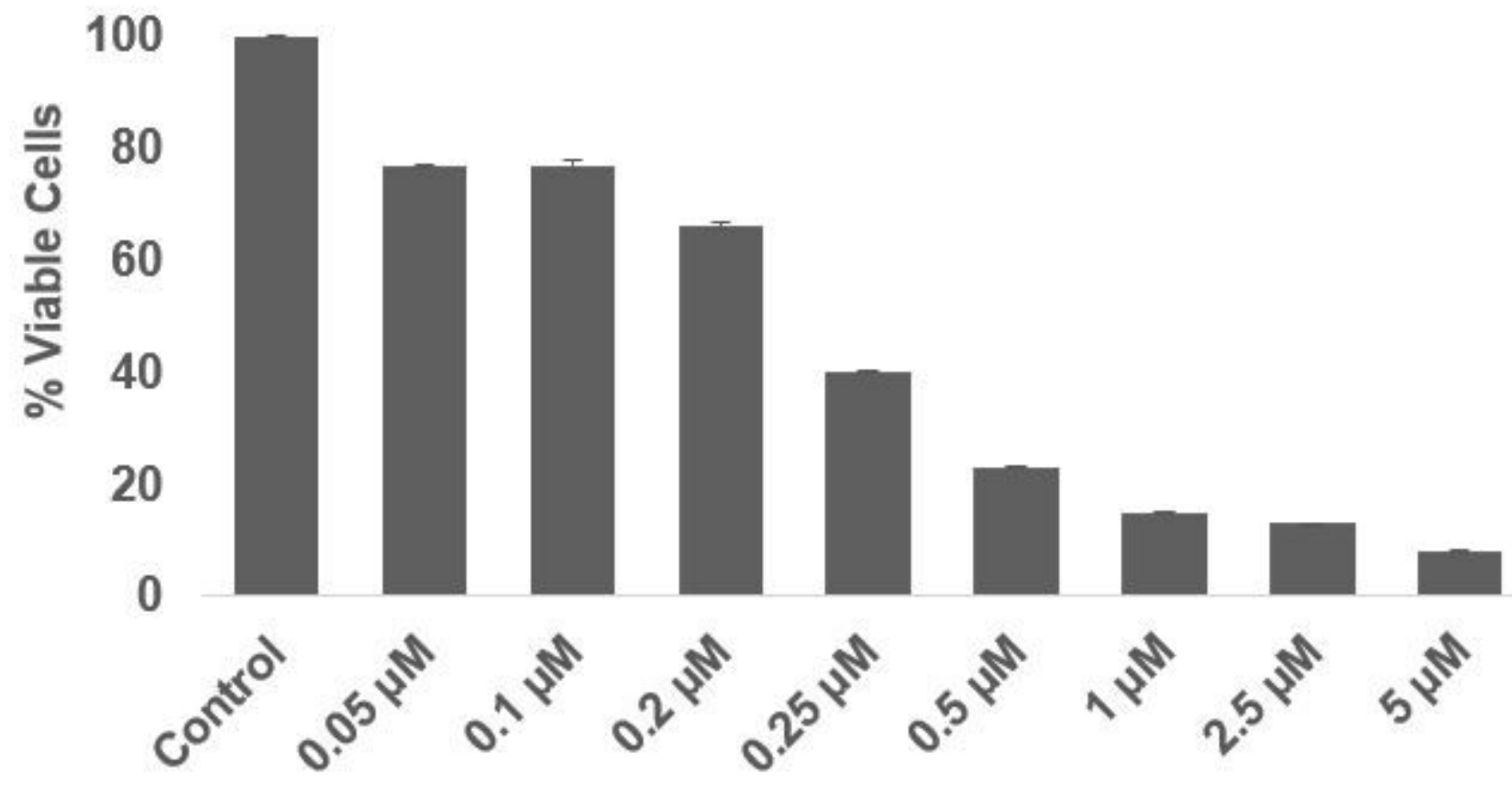


Figure 6

Pancreatic cancer cell lines, BxPC-3 exposed to various concentrations of 2 in DMSO. Control represents cells exposed to DMSO.

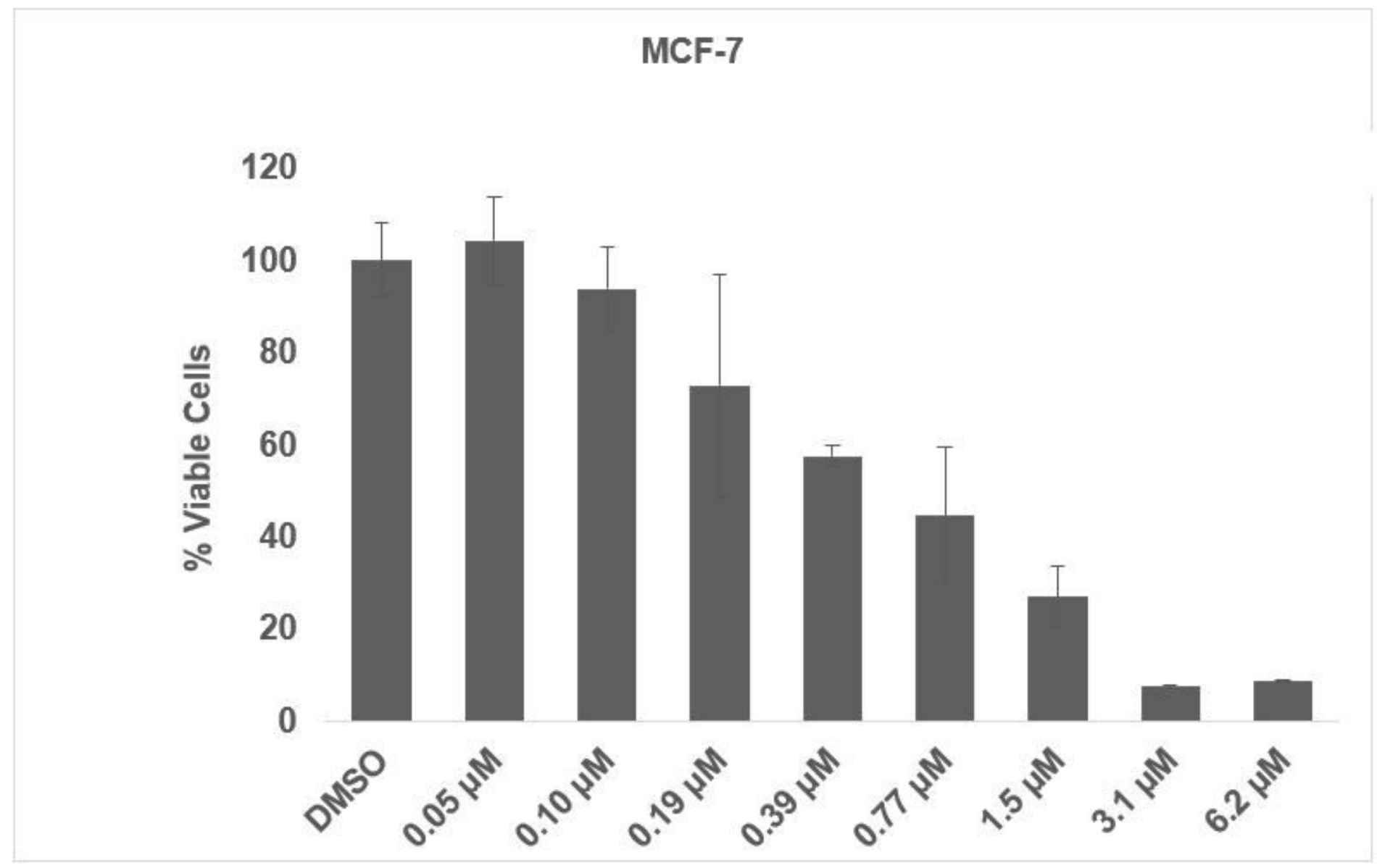

Figure 7

Breast cancer cell lines, MCF-7 exposed to various concentrations of 2 in DMSO. Control represents cells exposed to DMSO. 


\section{MDA-MB-231}

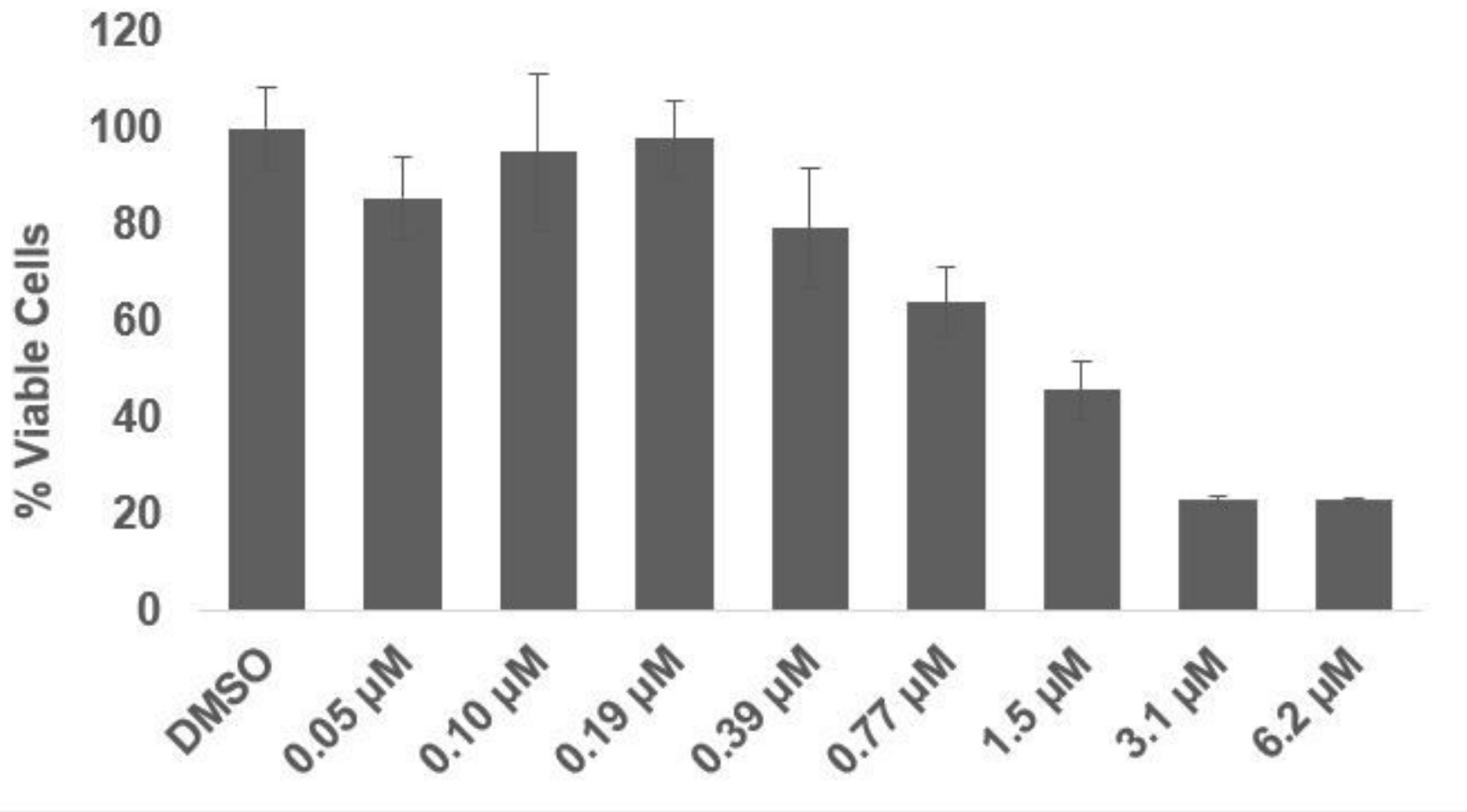

Figure 8

Breast cancer cell lines, MDA-MB-231 exposed to various concentrations of 2 in DMSO. Control represents cells exposed to DMSO. 


\section{U-937}

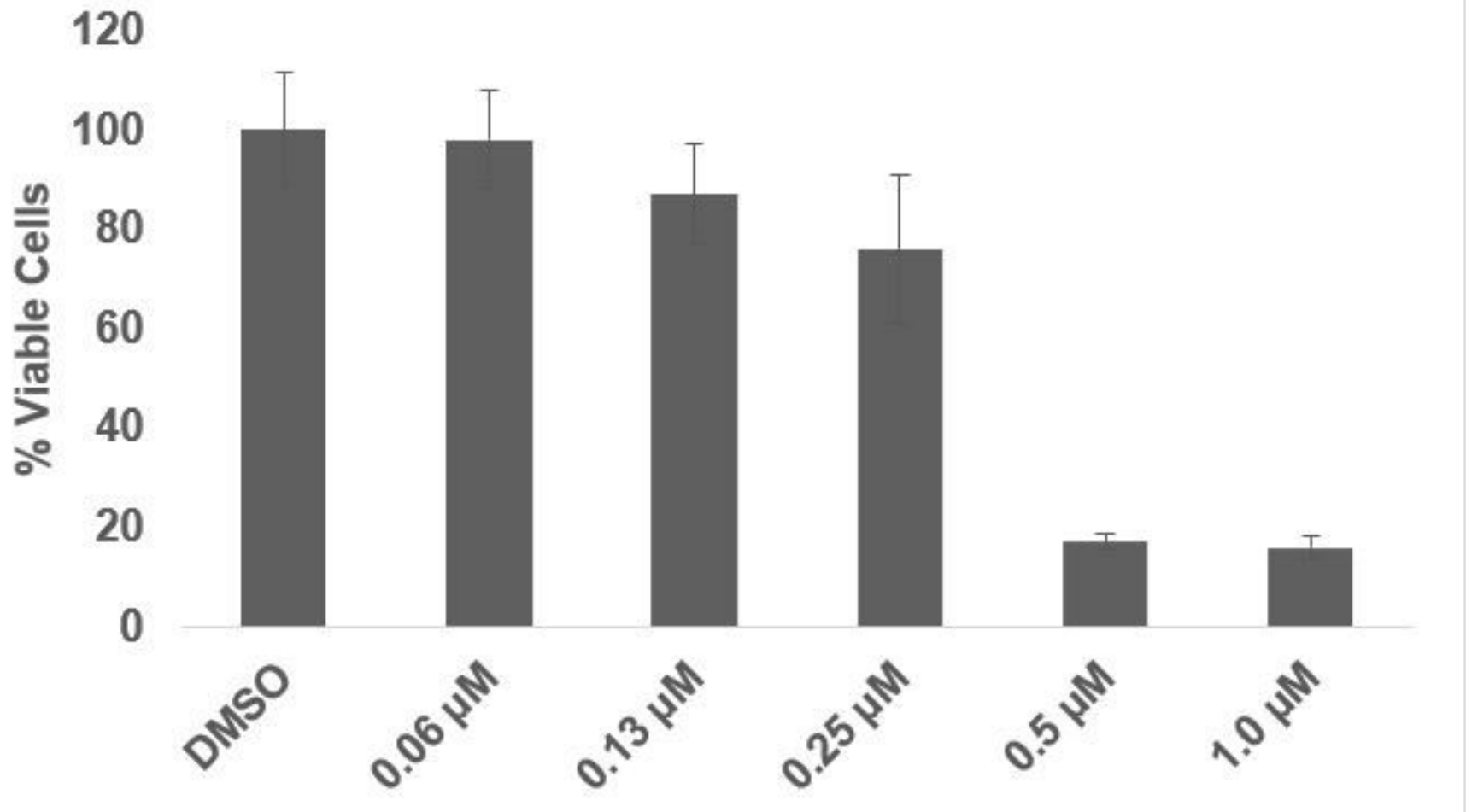

Figure 9

Lymphoma cell lines, U-937 exposed to various concentrations of 2 in DMSO. Control represents cells exposed to DMSO.

\section{Supplementary Files}

This is a list of supplementary files associated with this preprint. Click to download.

- equation.docx

- scheme1.jpg 